\title{
A technique to dissect the alimentary canal of the coffee berry borer (Hypothenemus hampei), with isolation of internal microorganisms
}

\author{
J.A. Ceja-Navarro, ${ }^{1}$ E.L. Brodie, ${ }^{1}$ F.E. Vega ${ }^{2}$ \\ ${ }^{1}$ Ecology Department, Earth Sciences Division, Lawrence Berkeley National Laboratory, Berkeley, \\ CA; ${ }^{2}$ Sustainable Perennial Crops Laboratory, U.S. Department of Agriculture, Agricultural \\ Research Service, Beltsville, MD, USA
}

\begin{abstract}
A technique for dissecting the alimentary canal of the coffee berry borer, Hypothenemus hampei, is presented. The technique was developed to isolate and identify alimentary canal-associated microorganisms that might be involved in caffeine detoxification.
\end{abstract}

\section{Introduction}

The coffee berry borer, Hypothenemus hampei (Ferrari) (Coleoptera: Curculionidae: Scolytinae), is a minute bark beetle, with females measuring ca. 1.5-2.0 mm in length and males being even smaller, ca. 1-1.2 mm long. The insect, endemic to Africa, is now pres

Correspondence: Javier A. Ceja-Navarro, Lawrence Berkeley National Laboratory, Earth Sciences Division, Ecology Department. 1 Cyclotron Rd. MS 70A-3317, Berkeley CA, 94720, USA. Tel. +1.510.486.7709.

E-mail: JCNavarro@lbl.gov

Key words: alimentary canal, coffee berry borer, dissection, Hypothenemus microbiota, caffeine.

Acknowledgements: this work was partially funded by United States Department of Agriculture, Agricultural Research Service Interagency Agreement No. 60-12-0-382 with Lawrence Berkeley National Laboratory and through Contract No. DE-AC02-05CH11231 between Lawrence Berkeley National Laboratory and the U. S. Department of Energy. J. A. Ceja-Navarro received support from the Mexican Consejo Nacional de Ciencia y Tecnología (CONACyT).

Received for publication: 13 May 2012.

Revision received: 28 October 2012.

Accepted for publication: 14 November 2012.

(C) Copyright J.A. Ceja-Navarro et al., 2012

Licensee PAGEPress, Italy

Journal of Entomological and Acarological Research 2012; 44:e21

doi:10.4081/jear.2012.e21

This article is distributed under the terms of the Creative Commons Attribution Noncommercial License (by-nc 3.0) which permits any noncommercial use, distribution, and reproduction in any medium, provided the original author(s) and source are credited. ent in most coffee producing countries and causes yearly losses estimated at over US $\$ 500$ million (Vega et al., 2002b), making the coffee berry borer the most economically important pest of coffee.

The coffee berry borer exhibits a cryptic life cycle inside the coffee berry, initiated by a colonizing female that oviposits in galleries within the berry and producing progenies with skewed sex ratios (10:1) favoring females (Vega et al., 2002a). The progeny feeds on the two coffee seeds within the berry, thereby reducing yields and the quality of the marketable product. Once insects molt into adults, there is sibling mating, followed by inseminated females emerging from the berry in search of new berries to colonize.

One of the most fascinating aspects of the basic biology of the coffee berry borer is its ability to survive on a food source containing caffeine (Vega et al., 2003), a purine alkaloid that inhibits insect feeding (Nathanson, 1984; Vega et al., 2003). The mechanisms used by the coffee berry borer to breakdown caffeine are not known, but might be related to the presence of microorganisms in the alimentary canal (i.e., foregut, midgut, and hindgut). One of the main obstacles to identify these microorganisms is the difficulty in dissecting the alimentary canal of such a small insect. Few techniques for the dissection of alimentary canals in beetles have been published, and most of the available information describes the dissecting procedures of rather large specimens, i.e. $>5 \mathrm{~mm}$ long (Hanley \& Ashe, 2003). We have developed a technique useful in dissecting the alimentary canal of the coffee berry borer for subsequent identification of microorganisms using molecular procedures.

\section{Materials and methods}

\section{Insects}

Coffee berry borers were reared on artificial diet containing ground green coffee beans, sugar, casein, powdered yeast, and preservatives (Portilla, 1999) and kept in the dark at $28^{\circ} \mathrm{C}$.

\section{Surface sterilization and dissection}

The technique is based on first sterilizing the cuticle by placing the insect in a $1.5 \mathrm{~mL}$ microcentrifuge tube containing $500 \mu \mathrm{L}$ absolute ethanol, and vigorously shaking for ca. $30 \mathrm{~s}$. The insect is then removed with sterile tweezers and transferred to another microcentrifuge tube containing $500 \mu \mathrm{L}$ undiluted commercial bleach (6\% sodium hypochlorite) and shaken for ca. $30 \mathrm{~s}$. Finally, the insect is washed three separate times in microcentrifuge tubes containing $500 \mu \mathrm{L}$ of sterile $1 \mathrm{X}$ phosphate buffered saline (PBS; diluted from 10X PBS pH 7.4; Ambion, Inc. Austin, TX, USA). This sterilization technique is effective in killing organisms present on the insect cuticle based on the lack of growth after 
plating aliquots from the last PBS wash. Once the insect is removed from the final PBS wash, it is placed on an $8 \mu \mathrm{L}$ drop of sterile $1 \mathrm{X}$ PBS in a sterile plastic Petri dish (Figure 1A). An additional PBS drop is placed in the dish for subsequent transfer of the insect, as described below.

The first step in the dissection process is to move the insect away from the PBS drop (Figure 1B) and to lightly press down on the elytral suture with tweezers to prompt the elytra and wings to spread open (Figure 1C). This facilitates their removal with tweezers (Figure 1D). The insect, now lacking the elytra and wings, can then be transferred to the second PBS drop (Figure 1E). The head is then held with tweezers and the dorsal side of the abdominal integument is removed by pulling and carefully peeling posteriorly with sterile tweezers (Figure 1F). The abdominal cavity is then cleared of extraneous material (e.g., cuticular segments, fat bodies, etc.) and the ventral side of the abdomen is excised, leaving the alimentary canal attached to the head (Figure 1G). By placing light pressure on the head (with the tweezers), the crop will move posteriorly, and the head can be removed.

Ten dissected alimentary canals were transferred to a sterile $1.5 \mathrm{~mL}$ microcentrifuge tube containing $500 \mu \mathrm{L}$ of sterile $1 \mathrm{X}$ PBS and homogenized with a sterile tissue homogenizer. The homogenized tissue solution was diluted (1:100) in $1 \mathrm{X}$ PBS and $10 \mu \mathrm{L}$ of the dilution were plat- ed onto sterile tryptic soy agar (Sigma-Aldrich, St. Louis, MO, USA) and incubated at $30^{\circ} \mathrm{C}$ until colonies were well-developed. Individual colonies were transferred to tryptic soy broth (Sigma-Aldrich) and incubated for $24 \mathrm{~h}$ at $30^{\circ} \mathrm{C}$ and $200 \mathrm{rpm}$. The bacterial cells were then harvested and their DNA extracted using the DNeasy Blood and Tissue kit (QIAGEN, Valencia, CA, USA) following the manufacturer's protocol. The DNA was used for polymerase chain reaction (PCR)-amplification of the 16rS DNA using the universal bacterial primers $27 \mathrm{~F}$ and $1492 \mathrm{R}$ (Polz \& Cavanaugh, 1998). PCR products were sequenced for subsequent phylogenetic analysis.

\section{Results}

The technique described above can be reliably used to dissect the entire alimentary canal, starting with the crop and ending with the anal opening (Figure $1 \mathrm{H})$. The mean length $(\mathrm{n}=5)$ of the alimentary canal is $3.5 \mathrm{~mm}$ (Figure $1 \mathrm{H}$ ).

Once dissected, the alimentary canal can be transferred to a sterile microcentrifuge tube containing $1 X$ PBS, where it can be macerated, fol-

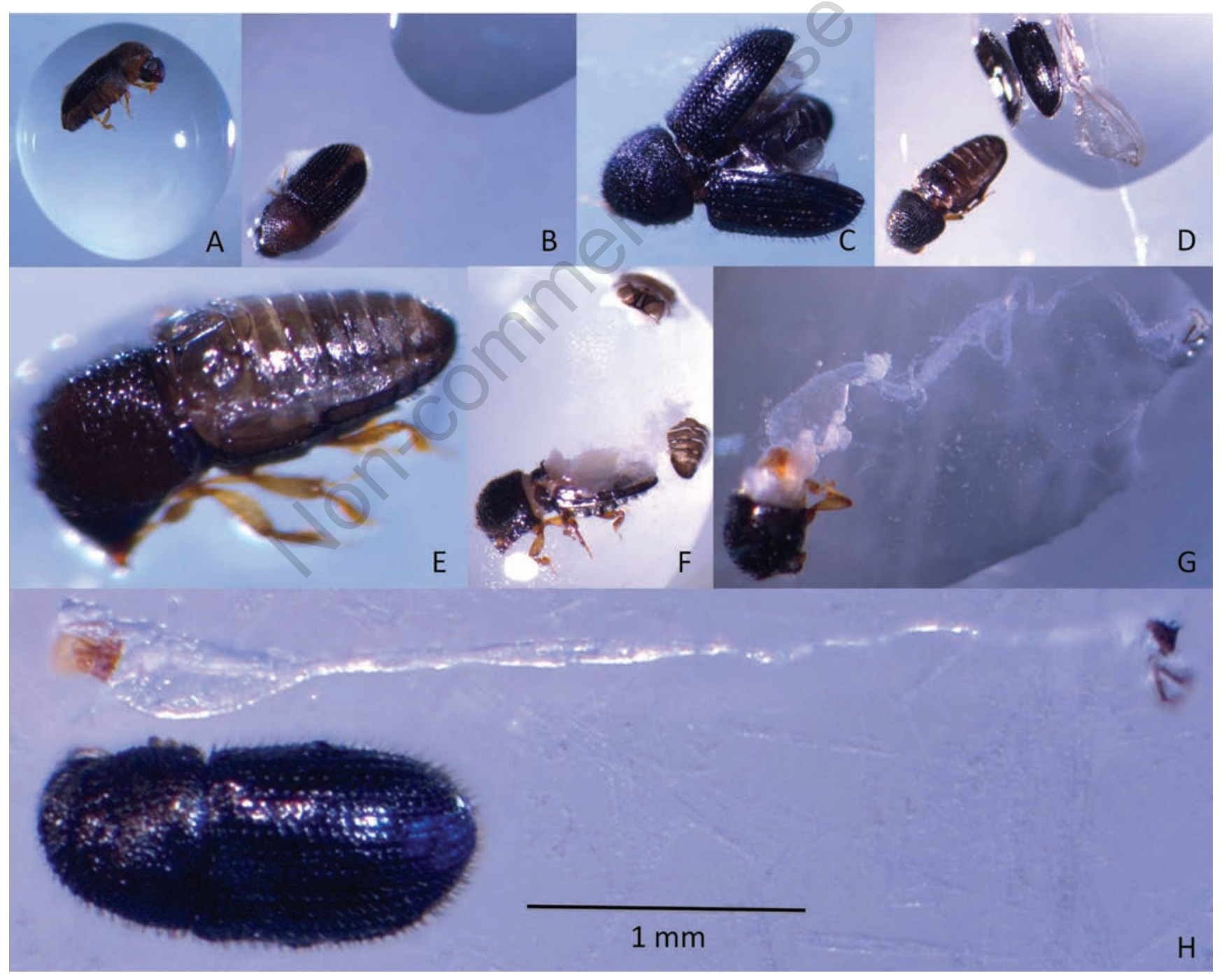

Figure 1. Methodology used for the dissection of the alimentary canal of the coffee berry borer. 
lowed by plating on different media for the recovery of culturable organisms. These can then be used for physiological studies or for the direct extraction of DNA/RNA. The dissection technique has yielded 20 bacterial species that have been identified based on 16S rDNA gene sequences as members of the Actinomycetales, Sphingomonadales, Rhizobiales, Pseudomonadales, Xanthomonadales, and Enterobacteriales.

\section{Discussion}

As part of our efforts to elucidate the role of the microbial communities associated with the coffee berry borer in the breakdown of caffeine, we developed an alimentary canal dissection technique that can be used in the analysis of the microbiota associated with small beetles. The dissection of the alimentary allowed us to isolate different species of bacteria by traditional culturing techniques, and can be also used to extract DNA/RNA for the screening of genes and microbial communities. The role of the isolated microorganisms on the biology of the coffee berry borer is the focus of ongoing research (Ceja-Navarro et al., 2012, unpublished data).

\section{References}

HANLEY R.S., ASHE J.S., 2003 - Techniques for dissecting adult aleocharine beetles (Coleoptera: Staphylinidae). Bull. Entomol. Res. 93: 11-18.

NATHANSON J.A., 1984 - Caffeine and related methylxanthines: possible naturally occurring pesticides. Science 226: 184-187.

POLZ M.F., CAVANAUGH C.M., 1998 - Bias in template-to-product ratios in multitemplate PCR. Appl. Environ. Microbiol. 64: 3724-3730.

PORTILLA M., 1999 - Mass rearing technique for Cephalonomia stephanoderis (Hymenoptera: Bethylidae) on Hypothenemus hampei (Coleoptera: Scolytinae) developed using Cenibroca artificial diet. Rev. Colom. Entomol. 25: 57-66.

VEGA F.E., BENAVIDES P., STUART J., O'NEILL S.L., 2002a - Wolbachia infection in the coffee berry borer (Coleoptera: Scolytidae). Ann. Entomol. Soc. Am. 95: 374-378.

VEGA F.E., BLACKBURN M.B., KURTZMAN C.P., DOWD P.F., 2003 Identification of a coffee berry borer-associated yeast: doest it break down caffeine? Entomol. Exp. Appl. 107: 19-24.

VEGA F.E., FRANQUI R.A., BENAVIDES P., 2002b - The presence of the coffee berry borer, Hypothenemus hampei, in Puerto Rico: fact or fiction? J. Insect. Sci. 2: 13. 